BULLETIN OF POLTAVA
STATE AGRARIAN
ACADEMIV

V. A. Levytska ${ }^{1 *}$

A. V. Berezovskyi ${ }^{2}$

A. B. Mushynskyi ${ }^{1}$

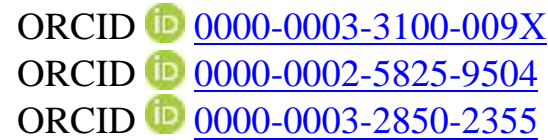

ORCID (iD) 0000-0003-3100-009X

ORCID (iD) 0000-0003-2850-2355

${ }^{1}$ Podillia State Agrarian and Engineering University, 13, Shevchenka str., Kamianets-Podilskyi, 32300, Ukraine

${ }^{2}$ Sumy National Agrarian University, 160, Gerasima Kondratieva str., Sumy, 40000, Ukraine

*Corresponding author

E-mail: Levytska28@gmail.com

How to Cite

Levytska, V. A., Berezovskyi, A. V., \& Mushynskyi, A. B. (2020). Diagnostics of dog anaplasmosis. Bulletin of Poltava State Agrarian Academy, (2), 252-258. doi: 10.31210/visnyk2020.02.32

Granulocytic anaplasmosis is a disease caused by small obligate intracellular bacteria of the Rickettsiales series, namely Anaplasma phagocytophilum, transmitted by ticks. People, dogs, cats, horses, sheep, goats, cattle, llamas can suffer from it. Diagnostics of dog anaplasmosis is usually based on analyzing epizootic data, clinical signs, hematological, biochemical, serological tests and, PCR. The research was conducted in the veterinary clinic "Fauna-Service"in Kamyanets-Podilsky, Khmelnytsky region during 20182019. Dogs of different ages, breeds and sexes were examined in the clinic. The study included 13 dogs with a positive PCR result on the DNA of A. phagocytophilum. All 13 dogs had an acute form of the disease. Most dogs had nonspecific clinical signs such as indolence and decreased motional activity. Diarrhea and vomiting were rarely registered. During physical examination, the dogs were not active. Hyperthermia (from 39.7 to $41.2^{\circ} \mathrm{C}$ ), tachycardia and polypnea were recorded. Biochemical blood examination revealed a slight decrease in total protein in 10 dogs $(53.57 \pm 1.36 \mathrm{~g} / \mathrm{l})$ and albumin in 6 dogs $(23.01 \pm 1.31 \mathrm{~g} / \mathrm{l})$. Hematological changes included thrombocytopenia in 11 dogs $\left(110.95 \pm 5.71 \times 10^{9} / \mathrm{l}\right)$ and anemia in 8 dogs (erythrocyte number $4.55 \pm 0.36 \times 10^{12} /$; hemoglobin concentration $94.28 \pm 5.85 \mathrm{~g} / \mathrm{l}$; hematocrit: $32.92 \%$ ). Leukocytosis was also observed in 2 dogs $\left(10.25 \pm 1.87 \times 10^{9} / l\right)$. Besides, increased enzymes in 8 dogs and hyperbilirubinemia in 5 dogs were the most common abnormalities. The concentration of bilirubin was above normal (23.98 $\pm 6.65 \mu \mathrm{mol} / \mathrm{l})$; alkaline phosphatase - $113.53 \pm 15.58 \mathrm{u} / \mathrm{l}, \mathrm{ALT}-117.74 \pm 14.44 \mathrm{u} / \mathrm{l}$, AST $70.98 \pm 9.15 \mathrm{u} / \mathrm{l}$. Small oval basophilic intra-cytoplasmic inclusions (morulae) having the size of 2 to $3 \mu \mathrm{m}$, corresponding to A. phagocytophilum were found in neutrophils of blood smears of 9 dogs. Renal azotemia was observed in urine analysis of only some dogs. All 13 dogs were treated on an outpatient basis. For the final establishment and confirmation of the diagnosis, it is necessary to conduct blood test by PCR method. Thus, granulocytic anaplasmosis should be considered as a probable diagnosis in dogs during the period of tick activity in Khmelnytsky region.

Key words: dog granulocytic anaplasmosis, tick-borne disease, diagnostics

\title{
ДІАГНОСТИКА АНАПЛАЗМОЗУ В СОБАК
}

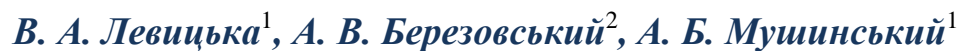

${ }^{1}$ Подільський державний аграрно-технічний університет, м. Кам’янець-Подільський, Україна

${ }^{2}$ Сумський національний аграрний університет, м. Суми, Україна

Гранулоцитарний анаплазмоз - трансмісивне захворювання, щэо спричинясться дрібними облігатними внутрішньоклітинними бактеріями ряду Rickettsiales, а саме Anaplasma phagocytophilum. Можуть хворіти 


\section{ВЕТЕРИНАРНА МЕДИЦИНА}

люди, собаки, коти, коні, вівиі, кози, велика рогата худоба, лами. Дослідження проводили на базі ветеринарної клініки «Фауна-Сервіс» м. Кам'янещь-Подільського Хмельниџької області протягом 2018-2019 років. На прийом до клініки потрапляли собаки різного віку, породи та статі. У дослідження було включено 13 собак з позитивним ПЛР результатом на ДНК А. phagocytophilum. У всіх 13 собак спостерігали гостру форму захворювання. Більшість собак мали неспецифічні клінічні ознаки, такі як млявість та знижена рухова активність. Рідко спостерігались діарея та блювота. При фізичному огляді собаки були неактивними. Реєстрували гіпертермію (від 39,7 до 41,20 ${ }^{\circ} \mathrm{C}$ ), тахікардію та поліпноє. Біохімічне дослідження крові виявило незначне зниження загального білка у 10 собак (53,57士1,36 г/л) і альбуміну в 6 собак $(23,01 \pm 1,31$ г/л). Гематологічні зміни включали тромбоцитопенію в 11 собак

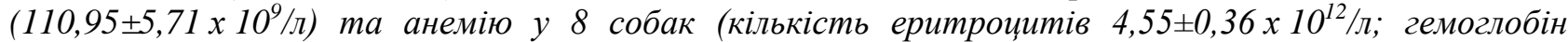

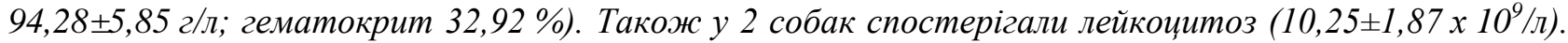
Крім того, найпоширенішими відхиленнями було підвищення ферментів у 8 собак та гіпербілірубіне-

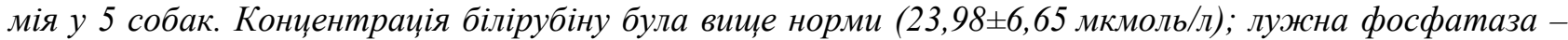

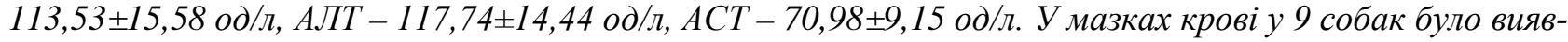
лено в нейтрофілах невеликі овальні базофільні внутрішньоцитоплазматичні включення (морули) розміром від 2 до 3 мкм, що відповідали A. phagocytophilum. Для остаточного встановлення $і$ підтвердження діагнозу необхідне проведення аналізу крові методом ПЛР. Отже, гранулоцитарний анаплазмоз необхідно вважсати як диференційний діагноз у собак у період активності кліщів у Хмельницькій області.

Ключові слова: гранулоцитарний анаплазмоз собак, діагностика

\section{ДИАГНОСТИКА АНАПЛАЗМОЗА У СОБАК}

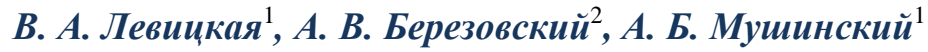

${ }^{1}$ Подольский государственный аграрно-технический университет, г. Каменец-Подольский, Украина

${ }^{2}$ Сумской национальный аграрный университет, г. Сумы, Украина

Гранулоичитарный анаплазмоз собак - трансмиссивное заболевание, вызываемое мелкими облигатнылми внутриклеточными бактериями ряда Rickettsiales, а именно Anaplasma phagocytophilum. Исследования проводились на базе ветеринарной клиники Хмельниикой области в течение 2018-2019 годов. В исследование было включено 13 собак с положительным ПЦР результатом на ДНК A. phagocytophilum. У всех собак наблюдали острую форму заболевания. Большинство собак имели неспецифические клинические признаки, такие как вялость и пониженная двигательная активность. Регистрировали гипертермию (от 39,7 до 41,2 ${ }^{\circ} \mathrm{C}$ ), тахикардию и полипноэ. Лабораторно обнаружили незначительное снижение общего белка и альбумина, тромбоцитопению, анемию, лейкоцитоз и гипербилирубинемию. В мазках крови у 9 собак были обнаружены в нейтрофилах небольшие моруль размером от 2 до 3 мкм.

Ключевые слова: гранулоцитарный анаплазмоз собак, диагностика

Вступ

Рикетсії - це дрібні облігатні внутрішньоклітинні бактерії ряду Rickettsiales, які є збудниками трансмісивних хвороб. Вони поділяються на дві родини - Anaplasmataceae та Rickettsiaceae, що включають види, які передаються різними видами кліщів, циркулюють у дикій природі і можуть призводити до захворювань у людей, собак та інших тварин $[1,2]$.

У країнах Свропи в домашніх собак реєструється Anaplasma phagocytophilum (раніше Ehrlichia phagocytophila) та Anaplasma platys (раніше Ehrlichia platys). Вони інфікують переважно нейтрофільні та рідко еозинофільні гранулоцити (A. phagocytophilum) або тромбоцити (A. platys) та спричиняють захворювання, які без лікування можуть призвести до загибелі тварин [3].

A. phagocytophilum спричиняє гранулоцитарний анаплазмоз у собак, також можуть хворіти люди, коти, коні, вівці, кози, велика рогата худоба, лами. Резервуарними господарями можуть бути косуля, олень, дрібні гризуни, рись. Захворювання переносять кліщі роду Ixodes. Анаплазмоз реєструють у регіонах, де зустрічаються іксодові кліщі. Поширеність A. phagocytophilum у Свропі серед кліщів I. ricinus коливається від $<1 \%$ до $20 \%$, а серед кліщів I. persulcatus у східній Європі від $2 \%$ до $17 \%$, крім того, ДНК A. phagocytophilum було виявлено в голодних кліщів виду D. reticulatus [4, 5]. 


\section{ВЕТЕРИНАРНА МЕДИЦИНА}

Від початку живлення кліща до потрапляння збудника у кров собаки зазвичай необхідно 24-48 годин. Інкубаційний період у ссавців становить 1-2 тижні. Після ендоцитозу A. phagocytophilum розвивається шляхом бінарного поділу в морули переважно в нейтрофілах та рідко еозинофілах. Клітини, інфіковані A. phagocytophilum, виявляють у крові, а також у тканинах мононуклеарної фагоцитарної системи, таких як селезінка, печінка та кістковий мозок [6, 7].

При анаплазмозі, як правило, спостерігаються неспецифічні клінічні ознаки: млявість, анорексія та лихоманка; поверхневі крововиливи та кровотечі (петехії, мелена, епістаксис), кульгавість (поліартрит), бліді слизові оболонки, діарея, блювота, тахіпное, спленомегалія, лімфоаденопатія. До рідкісних клінічних ознак відносять кашель, увеїт, набряк кінцівок, полідипсію та поліурію [8].

До найбільш поширених лабораторних знахідок відносяться тромбоцитопенія, нерегенеративна нормоцитарна нормохромна анемія, лімфопенія, моноцитоз, лейкопенія та лейкоцитоз, гіперглобулінемія, гіпоальбумінемія, підвищення рівня печінкових ферментів (лужна фосфатаза). Рідко спостерігається гіпербілірубінемія, ниркова азотемія [9].

A. platys спричиняє рецидивуючу тромбоцитопенію собак. Спосіб передачі збудника точно не встановлений, але переносниками можуть бути кліщі та інші членистоногі. У разі експериментального зараження збудником інкубаційний період триває від 8 до 15 діб. Найвищий рівень збудника у крові спостерігається під час початкового піку захворювання. В подальшому уражується лише близько $1 \%$ тромбоцитів, тоді як тромбоцитопенічні коливання залишаються. 3 часом вираженість реакції тромбоцитів зменшується.

Серед клінічних ознак, що виникають, найчастіше спостерігається лихоманка, млявість, анорексія, бліді слизові оболонки, петехії, виділення з носа та лімфаденомегалія. Лабораторно реєструється рецидивуюча тромбоцитопенія (циклічна бактеріємія та тромбоцитопенія $(<20000$ /мкл) 3 інтервалом $1-2$ тижні), нерегенеративна нормоцитарна нормохромна анемія, гіперглобулінемія, гіпоальбумінемія [6].

Діагностика анаплазмозу в собак, як правило, базується на аналізі епізоотичних даних, клінічних ознак, гематологічних, біохімічних, серологічних досліджень, а також ПЛР [10].

Антитіла до A. phagocytophilum або A. platys можуть бути виявлені за допомогою непрямого імунофлуоресцентного аналізу (IFA). Сероконверсія може спостерігатися через 1-4 тижні після зараження, тому собаки з гострими проявами захворювання можуть бути серологічно негативними. Однак в ендемічних районах позитивні результати дослідження можуть вказувати на зараження в минулому, а не обов'язково на гостре захворювання. Як правило, необхідно провести два серологічні дослідження з інтервалом у 3-4 тижні, щоб встановити, чи відбулася сероконверсія. Позитивний результат одного серологічного тесту в поєднанні з клінічними ознаками не є підставою для встановлення діагнозу на анаплазмоз. Важливо зазначити, що A. phagocytophilum може мати перехресні реакції 3 іншими збудниками, такими як A. platys та Coxiella burnetti [6].

На основі імунохроматографічних та імуноферментних методів діагностики для практикуючих лікарів розроблені комерційні набори для швидкої діагностики на місці, так звані експрес-тести.

Спеціальні дослідження на виявлення A. phagocytophilum та A. platys проводять у спеціалізованих лабораторіях. Позитивний результат ПЛР є підставою для підтвердження захворювання.

Остаточний діагноз встановлюється при виявленні морул у нейтрофільних (рідше еозинофільних) гранулоцитах (A. phagocytophilum) або тромбоцитах (A. platys) при мікроскопічному дослідженні мазків крові. Позитивні результати досліджень повинні бути підтверджені за допомогою ПЛР.

Отже, метою роботи було охарактеризувати основні клінічні ознаки анаплазмозу в собак у західному регіоні України. Для цього були поставлені такі завдання: провести епізоотологічні, клінічні та лабораторні дослідження у разі анаплазмозу в собак.

\section{Матеріали і методи досліджень}

Дослідження проводили на базі ветеринарної клініки «Фауна-Сервіс» м. Кам’янець-Подільського Хмельницької області протягом 2018-2019 років. На прийом до клініки потрапляли собаки різного віку, породи та статі. Діагноз встановлювали на основі клінічних ознак, епізоотологічних даних та лабораторних досліджень. Лабораторні дослідження включали загальний аналіз крові (з лейкоформулою) та біохімічне дослідження крові, сечі, експрес-тести CaniV-4 (Vet Expert, Польща), ПЛР тестування, рентгеноскопію, УЗД.

Гематологічні дослідження проводили за допомогою напівавтоматичних аналізаторів Micro CC-20 Plus (HTI, США) та BioChem SA (HTI, США). Кров попередньо відбирали у пробірки. Мікроскопічне дослідження мазків крові проводили за допомогою мікроскопа Konus 5605 Biorex-3. Дослідження се- 


\section{ВЕТЕРИНАРНА МЕДИЦИНА}

чі проводили за допомогою мікроскопії та аналізатора Laura Smart [11].

Серед 13 хворих собак найпоширенішими породами були метиси (6), німецька вівчарка (4), хаскі (2), доберман (1). Всього 7 сук та 6 кобелів. Вік собак коливався від 1 до 12 років.

Собак обстежували на наявність інших збудників трансмісивних хвороб залежно від клінічних ознак та історії хвороби. Собак перевіряли на бабезіоз, що є ендемічним для України $[12,13]$. Якщо в собак виявляли ознаки болю в суглобах або поліартрит, їх перевіряли на бореліоз. 24 собаки були протестовані на Anaplasma phagocytophilum, Babesia canis, Borrelia burgdorferi s. l. та Ehrlichia canis методом полімеразної ланцюгової реакції (ПЛР). Дослідження проводили на кафедрі паразитології та інвазійних хвороб Варшавського університету природничих наук (Варшава, Польща). Одержані цифрові дані опрацьовували статистично.

\section{Результати досліджень та їх обговорення}

Протягом 2018-2019 років 24 собаки були протестовані на A. phagocytophilum, використовуючи метод ПЛР. Всього 19 собак були ПЛР-позитивними, але 6 із них були виключені з дослідження: у двох собак не вдалося визначити, чи були клінічні ознаки внаслідок анаплазмозу чи внаслідок супутніх захворювань, у чотирьох було виявлено B. canis. Отже, у дослідження було включено 13 собак 3 позитивним ПЛР результатом на ДНК А. phagocytophilum.

У всіх 13 собак спостерігали гостру форму захворювання. Більшість собак мали неспецифічні клінічні ознаки, такі як млявість та знижена рухова активність. Рідко спостерігались діарея та блювота. При клінічному огляді собаки були неактивними. Реєстрували гіпертермію (від 39,7 до $41,2{ }^{\circ} \mathrm{C}$ ), тахікардію

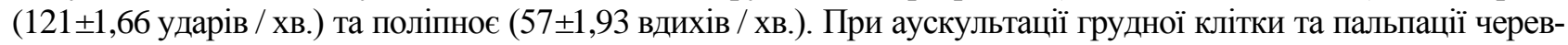
ної порожнини не виявляли жодних порушень. Відзначали також бліді видимі слизові оболонки. Також реєстрували збільшення та болючість лімфатичних вузлів. У деяких собак також спостерігали гнійні виділення з очей. У двох собак виявили крововиливи на слизових оболонках ротової порожнини. Діагностична рентгенографія грудної та черевної порожнини була зроблена 10 собакам. УзД дослідження провели у всіх собак. На основі рентгенології та УзД була виявлена спленомегалія у 8 собак; селезінка була сонографічно однорідною у всіх випадках. Також було виявлено однорідну гепатомегалію у 5 собак.

Біохімічне дослідження крові виявило незначне зниження загального білка у 10 собак, що в серед-

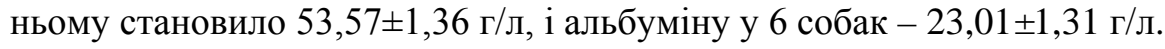

Гематологічні зміни включали тромбоцитопенію в 11 собак та анемію у 8 собак. Кількість тромбоцитів у середньому становила $110,95 \pm 5,71$ х $10^{9}$ /л, при нормі 120-460 х 109/л, кількість еритроци-

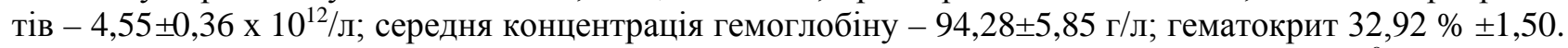
Також у 2 собак спостерігали лейкоцитоз, кількість лейкоцитів становила 10,25 $\pm 1,87$ x $10^{9}$ /л.

Крім того, найпоширенішими відхиленнями було підвищення ферментів у 8 собак та гіпербілірубінемія у 5 собак. Концентрація білірубіну була вище норми і в середньому становила

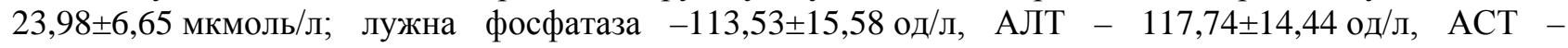

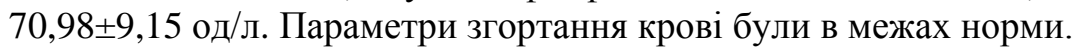

У мазках крові у 9 собак було виявлено в нейтрофілах невеликі овальні базофільні внутрішньоцитоплазматичні включення (морули) розміром від 2 до 3 мкм, що відповідали Anaplasma phagocytophilum (рис. 1).

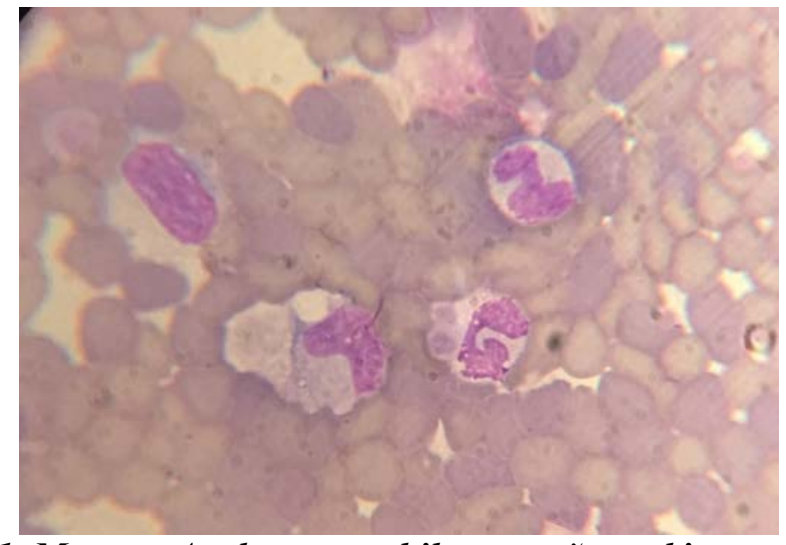

Рис. 1. Морули A. phagocytophilum у нейтрофілах собаки. Фарбування Лейкодиф-200 (х 1000). 
При аналізі сечі лише в деяких собак спостерігалась ниркова азотемія (креатинін

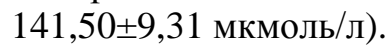

Також у клініці було проведено експрес-тестування да допомогою систем CaniV-4. Сім собак виявились негативними на антитіла до Anaplasma spp. при первинному огляді, а 6 - позитивними (рис. 2).

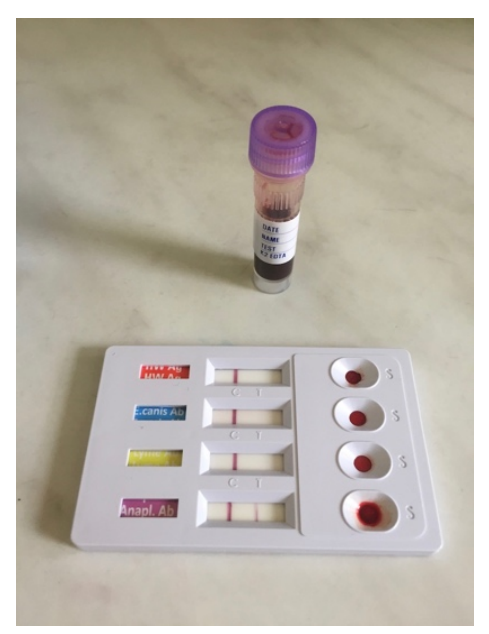

Рис. 2. Позитивний результат на антитіла до A. phagocytophilum, експрес-mесm CaniV-4

За допомогою ПЛР, у всіх 13 собак було підтвержено ДНК A. phagocytophilum у крові, ідентифікацію проводили за геном msp2.

Через 7, 14, 21 та 28 днів після початку лікування проводили повторний аналіз крові. Кількість еритроцитів повернулась до норми протягом 10 днів у 7 собак. У собак з легкою анемією гематокрит протягом тижня повернувся до базових значень, у інших на другий-третій тиждень. Кількість тромбоцитів нормалізувалася у 9 собак протягом першого тижня, у інших - протягом другого тижня.

Усім тваринам було рекомендовано проводити регулярну профілактичну обробку проти ектопаразитів протягом усього сезону активності кліщів, починаючи з весни та до пізньої осені.

Гранулоцитарний анаплазмоз собак було зареєстровано 2018-2019 років у Хмельницькій області. Захворювання реєстрували переважно у весняно-літні місяці, що свідчить про його сезонність, що пов'язана з появою іксодових кліщів, що відмічали також інші дослідники [15]. Однак є повідомлення про те, що клінічні ознаки захворювання можуть реєструватись і взимку. В цій місцевості кліщі виду D. reticulatus та I. ricinus $\epsilon$ широкорозповсюдженими $\mathrm{i} \epsilon$ переносниками збудника A. phagocytophilum. У попередніх наших дослідженнях було встановлено, що до 22 \% кліщів Ixоdes ricinus можуть бути переносниками анаплазмозу [16].

За нашими даними, анаплазмоз було зареєстровано у різних порід собак. Найбільш сприйнятливі породи собак не встановлені, однак найчастіше хворіють собаки з довгою шерстю або ті, які найбільше контактують із зовнішнім середовищем [17]. Також ми реєстрували лише гостру форму захворювання, що збігається з дослідженнями інших авторів $[9,18]$.

Діагностика анаплазмозу, як правило, є комплексною і включає аналіз клінічних та лабораторних досліджень. Загальними клінічними ознаками у всіх собак були млявість (92\%) та підвищення температури (77\%) [19, 20]. Досить часто в собак, хворих на анаплазмоз, спостерігаються проблеми 3 опорно-руховим апаратом, однак у нашому дослідженні таких порушень ми не виявляли [9, 20]. Інші патологічні клінічні ознаки, такі як полідипсія, поліурія, блювота, діарея траплялися рідко в цьому дослідженні, що відповідає наявній літературі. Лімфаденопатія спостерігалася часто. У попередніх дослідженнях не завжди було виключено наявність ко-інфекцій. Цей факт міг пояснити різні симптоми та особливо порушення з боку опорно-рухового апарату. Крім того, відомо, що в собак існує кілька генетичних варіантів A. phagocytophilum, що може бути причиною різних проявів клінічних ознак залежно від регіону [21].

У поточному дослідженні спленомегалію було зареєстровано загалом у 84 \% собак. Вказана патологія була задокументована також при експериментальному зараженні анаплазмозом унаслідок реактивної гіперплазії [22].

Лабораторний аналіз крові дає можливість виявити досить характерні порушення для цього захво- 


\section{ВЕТЕРИНАРНА МЕДИЦИНА}

рювання. При дослідженні мазків крові морули були виявлені у $69 \%$ мазків досліджених собак, хоча всі 100 \% собак були ПЛР-позитивними на анаплазмоз. Ці дані збігаються з дослідженнями інших авторів, у яких також морули не завжди були виявлені в нейтрофілах, однак за допомогою молекулярно-генетичних методів було підтверджено гранулоцитарний анаплазмоз [10, 19].

При дослідженнях крові найчастіше виявляли тромбоцитопенію. Вона спостерігалась у 11 собак, що становило 86 \% всіх випадків, та відповідає попереднім дослідженням [9, 18-20]. Також у нашому дослідженні було виявлено анемію у 8 собак, що можна порівняти з даними, отриманими іншими авторами [19]. Крім того, було зареєстровано лейкоцитоз (0,3\%), тоді як в інших дослідженнях частіше траплялася лейкопенія [7]. Підвищена активність ферментів (лужна фосфатаза, АЛТ, АСТ), гіпербілірубінемія, гіпопротеїнемія та гіпоальбумінемія були найпоширенішими біохімічними порушеннями. У закордонних дослідження також виявляли збільшення активності лужної фосфатази $[18,19]$.

\section{Висновки}

Отже, гранулоцитарний анаплазмоз необхідно вважати як диференційний діагноз у собак у період активності кліщів у Хмельницькій області. У тварин найчастіше спостерігаються такі клінічні ознаки, як лихоманка, млявість, а також тромбоцитопенія та анемія. Діагностика повинна включати епізоотичний аналіз, клінічні та лабораторні дослідження. Виявлення характерних морул у мазках є досить проблематичним і не завжди є ефективним. Експрес-тести на антитіла можуть бути негативними під час гострої фази захворювання, оскільки підвищення титру антитіл спостерігається пізніше, ніж клінічний прояв хвороби. Тому для остаточного встановлення і підтвердження діагнозу необхідне проведення аналізу крові методом ПЛР. Ефективним при лікуванні анаплазмозу є доксициклін.

Перспективи подальших досліджень полягають у вивченні інших трансмісивних хвороб, які можуть переноситись кліщами в західному регіоні України. На сьогодні це питання $є$ недостатньо вивченим і потребує проведення досліджень кліщів, проміжних та дефінітивних господарів для встановлення ареалів поширення та збудників таких захворювань як бабезіоз, ерліхіоз, бореліоз та ін.

\section{References}

1. Szewczyk, T., Werszko, J., Myczka, A. W., Laskowski, Z., \& Karbowiak, G. (2019). Molecular detection of Anaplasma phagocytophilum in wild carnivores in north-eastern Poland. Parasites \& Vectors, 12 (1). doi: 10.1186/s13071-019-3734-y.

2. Atif, F. A. (2015). Anaplasma marginale and Anaplasma phagocytophilum: Rickettsiales pathogens of veterinary and public health significance. Parasitology Research, 114 (11), 3941-3957. doi: 10.1007/s00436-015-4698-2.

3. Dumler, J. S., Barbet, A. F., Bekker, C. P., Dasch, G. A., Palmer, G. H., Ray, S. C., Rikihisa, Y., \& Rurangirwa, F. R. (2001).Reorganization of genera in the families Rickettsiaceae and Anaplasmataceae in the order Rickettsiales: unification of some species of Ehrlichia with Anaplasma, Cowdria with Ehrlichia and Ehrlichia with Neorickettsia, descriptions of six new species combinations and designation of Ehrlichia equi and 'HGE agent' as subjective synonyms of Ehrlichia phagocytophila. International Journal of Systematic and Evolutionary Microbiology 51, 2145-2165. doi: 10.1099/00207713-51-6-2145.

4. Jaarsma, R. I., Sprong, H., Takumi, K., Kazimirova, M., Silaghi, C., Mysterud, A., Rudolf, I., Beck, R., Foldvari, G., Tomassone, L., Groenevelt, M., Everts, R. R., Rijks, J. M., Ecke, F., Hornfeldt, B., Modry, D., Majerova, K., Votypka, J., \& Estrada-Peña, A. (2019). Anaplasma phagocytophilum evolves in geographical and biotic niches of vertebrates and ticks. Parasit Vectors 12, 328. doi: 10.1186/s13071-019-3583-8.

5. Stuen, S., Granquist, E. G., \& Silaghi, C. (2013). Anaplasma phagocytophilum -a widespread multihost pathogen with highly adaptive strategies. Frontiers in Cellular and Infection Microbiology, 3, 31. doi: 10.3389/fcimb.2013.00031.

6. Control of Vector-Borne Diseases in Dogs and Cats. ESCCAP Guideline 05 Third Edition - March 2019. Retrived from: https:/www.google.com/url?sa=t\&rct=j\&q=\&esrc=s\&source=web\&cd=\&cad=rja\&uact=8\&ved= 2ahUKEwi_4_imlrrqAhWJposKHSsoAfsQFjAAegQIAhAB\&url=https\%3A\%2F\%2Fwww.esccap.org\%2Fuploads \%2Fdocs\%2Fznkh6j1d_0775_ESCCAP_Guideline_GL5_v8_1p.pdf\&usg=AOvVaw1R2bfOiZM97azKA1K6kG1N.

7. Woldehiwet, Z. (2010). In-vitro studies on the susceptibility of ovine strains of anaplasma phagocytophilum to antimicrobial agents and to immune serum. Journal of Comparative Pathology, 143 (2-3), 94-100. doi: 10.1016/j.jcpa.2010.01.005.

8. Allison, R. W., \& Little, S. E. (2013). Diagnosis of rickettsial diseases in dogs and cats. Veterinary Clinical Pathology, 42 (2), 127-144. doi: 10.1111/vcp.12040. 


\section{ВЕТЕРИНАРНА МЕДИЦИНА}

9. Eberts, M. D., Vissotto de Paiva Diniz, P. P., Beall, M. J., Stillman, B. A., Chandrashekar, R., \& Breitschwerdt, E. B. (2011). Typical and Atypical Manifestations of Anaplasma phagocytophilumInfection in Dogs. Journal of the American Animal Hospital Association, 47 (6), e86-e94. doi: 10.5326/jaaha-ms-5578.

10. Chirek, A., Silaghi, C., Pfister, K., \& Kohn, B. (2017). Granulocytic anaplasmosis in 63 dogs: clinical signs, laboratory results, therapy and course of disease. Journal of Small Animal Practice, 59 (2), 112-120. doi: 10.1111 jsap.12787.

11. Carrade, D. D., Foley, J. E., Borjesson, D. L., \& Sykes, J. E. (2009). Canine granulocytic anaplasmosis: a review. Journal Veterinary International Medicine, 23 (6), 1129-1141. doi: 10.1111/j.19391676.2009.0384.x.

12. Solovy̆ova, L. M. (2012). Diahnostyka ta likuvannia za babeziozu sobak. Veterynarna Medytsyna, 96, 326-328 [In Ukrainian].

13. Prus, M. P., \& Pototskyi, M. K. (2003). Babezioz sobak. Veterynarna Medytsyna Ukrainy, 9, $24-26$ [In Ukrainian].

14. Ravnik, U., Tozon, N., Strasek, K., \& Zupanc, T. A. (2009). Clinical and haematological features in Anaplasma phagocytophilum seropositive dogs. Clinical Microbiology and Infection, 15, 39-40. doi: 10.1111/j.1469-0691.2008.02167.x.

15. Villeneuve, A., Goring, J., Marcotte, L., \& Overvelde, S. (2011). Seroprevalence of Borrelia burgdorferi, Anaplasma phagocytophilum, Ehrlichia canis, and Dirofilaria immitis among dogs in Canada. Canadian Veterinary Journal, 52, 527-530.

16. Levytska, V. A., \& Mushinsky, A. B. (2019). Monitoring of vector-borne diseases in the west part of Ukraine. Scientific Messenger of LNU of Veterinary Medicine and Biotechnologies, 21 (96), 14-18. doi: 10.32718/nvlvet9603.

17. Beck, S., Schreiber, C., Schein, E., Krücken, J., Baldermann, C., Pachnicke, S., von SamsonHimmelstjerna G., \& Kohn, B. (2014). Tick infestation and prophylaxis of dogs in northeastern Germany: A prospective study. Ticks and Tick-Borne Diseases, 5 (3), 336-342. doi: 10.1016/j.ttbdis.2013.12.009.

18. Granick, J. L., Armstrong, P. J., \& Bender, J. B. (2009). Anaplasma phagocytophiluminfection in dogs: 34 cases (2000-2007). Journal of the American Veterinary Medical Association, 234 (12), 1559-1565. doi: 10.2460/javma.234.12.1559.

19. Kohn, B., Galke, D., Beelitz, P., \& Pfister, K. (2008). Clinical features of canine granulocytic anaplasmosis in 18 naturally infected dogs. Journal of Veterinary Internal Medicine, 22 (6), 1289-1295. doi: 10.1111/j.1939-1676.2008.0180.x.

20. Ravnik, U., Bajuk, B. P., Lusa, L., \& Tozon, N. (2014). Serum protein profiles, circulating immune complexes and proteinuria in dogs naturally infected with Anaplasma phagocytophilum. Veterinary Microbiology, 173 (1-2), 160-165. doi: 10.1016/j.vetmic.2014.07.007.

21. Silaghi, C., Kohn, B., Chirek, A., Thiel, C., Nolte, I., Liebisch, G., \& Pfister, K. (2011). Relationship of Molecular and Clinical Findings on Anaplasma phagocytophilum Involved in Natural Infections of Dogs. Journal of Clinical Microbiology, 49 (12), 4413-4414. doi: 10.1128/jcm.06041-11.

22. Egenvall, A., Bjoersdorff, A., Lilliehook, L., Olsson Engvall, E., Karlstam, E., Artursson, K., Hedhammar, A., \& Gunnarsson, A. (1998). Early manifestations of granulocytic ehrlichiosis in dogs inoculated experimentally with a Swedish Ehrlichia species isolate. Veterinary Record, 143 (15), 412-417. doi: 10.1136/vr.143.15.412.

Стаття надійшла до редакції 18.05 .2020 р.

Левицька В. А., Березовський А. В., Мушинський А. Б. Діагностика анаплазмозу в собак. Вісник ПДАА. 2020. № 2. С. 252-258.

() Левичька Вікторія Андріївна, Березовський Андрій Володимирович, Мушинський Андрій Броніславович, 2020 